\title{
Plankton biodiversity in various typologies of inundation in Paminggir peatland, South Kalimantan, Indonesia on dry season
}

\author{
YUNANDAR $^{1,2, \boldsymbol{\varphi}}$, HEFNI EFFENDI ${ }^{3,4}$, WIDIATMAKA ${ }^{5}$, YUDI SETIAWAN ${ }^{4,6}$ \\ ${ }^{1}$ Program of Natural Resources and Environment Management, Graduate School, Institut Pertanian Bogor. Jl. Raya Pajajaran, Baranangsiang, Bogor \\ 16144, West Java, Indonesia. Tel./fax.: +62-251-8332779, `email: yunandar01@ulm.ac.id \\ ${ }^{2}$ Department of Aquatic Resource Management, Faculty of Fisheries and Marine, Universitas Lambung Mangkurat. Jl. Brigjen H. Hasan Basry \\ Banjarmasin 70123, South Kalimantan, Indonesia \\ ${ }^{3}$ Department of Aquatic Resource Management, Faculty of Fisheries and Marine Science, Institut Pertanian Bogor. Jl. Raya Dramaga, Bogor 16680, \\ West Java, Indonesia \\ ${ }^{4}$ Center for Environmental Research, Institut Pertanian Bogor. Jl. Raya Dramaga, Bogor 16680, West Java, Indonesia \\ ${ }^{5}$ Department of Soil Sciences and Land Resources, Faculty of Agriculture, Institut Pertanian Bogor. Jl. Raya Dramaga, Bogor 16680, West Java, \\ Indonesia \\ ${ }^{6}$ Department of Forest Resources Conservation and Ecotourism, Faculty of Forestry, Institut Pertanian Bogor. Jl. Raya Dramaga, Bogor 16680, West \\ Java, Indonesia
}

Manuscript received: 7 January 2020. Revision accepted: 11 February 2020.

\begin{abstract}
Yunandar, Effendi H, Widiatmaka, Setiawan Y. 2020. Plankton biodiversity in various typologies of inundation in Paminggir peatland, South Kalimantan, Indonesia on dry season. Biodiversitas 21: 1012-1019. The aim of the study was to analyze the typology of inundation areas and plankton biodiversity in Paminggir peatland, South Borneo, Indonesia. Typology of inundation was determined by image processing and spatial analysis using supervised classification method from Landsat 1994, 2014, 2019. Plankton biodiversity was determined using purposive sampling in detected inundation from spatial analysis. Some environmental factors like temperature, Ph and DO were also analyzed. Confirmation of the results of spatial analysis of peatland typology made from overall accuracy and Kappa informed $88.48 \%$ and 0.8 . The typology of permanent inundation decreased by $30 \%$ from 1994 to 2019 during the dry period from June to August of the total study area of 43275,584 hectares due to sedimentation, land conversion for settlement, and increase in water weeds. Inundation criteria with duration throughout the year were was categorized as permanent, whereas temporary inundation was tentative even in certain dry season. Plankton index biodiversity in permanent inundation was more varied compared to temporary inundation. Phytoplankton from the freshwater Chrysophyta group was more dominant, while zooplankton from the Nauplius group, which were the natural food for fish larvae always presented in the typology of permanent inundation.
\end{abstract}

Keywords: Inundation, peatland, plankton, spatial, typology

\section{INTRODUCTION}

Paminggir peatland was part of the inland water ecosystem which its use being dominated by inland fisheries activities (FAO 2011; Cooke et al. 2016; Lynch et al. 2017). The source of freshwater swamps came from the runoff of the Barito and Nagara rivers and critically dependent of rainwater during rainy seasons. The alternation of rainy and dry season determines the variation in net water input and water loss in Paminggir. In the rainy season, the whole area was inundated, but in dry season a critical condition occurred where the volume of water swamp decreases and in other parts of swamp is dry up for 1-3 months (Trinugroho and Mawardi, 2017). The swamp drying had resulted in a decrease in the production of inland fisheries in the whole of Paminggir region and the Hulu Sungai Utara Regency. However, availability of inundation was a major factor in the life of nekton and plankton as natural food for fish.

Understanding of pattern of biodiversity distribution is important and has attracted the attention of ecologists in recent years (Griselda et al. 2019). It has been generally understood that variation of species distribution is result of species adaptation to environmental gradient. In this term, understanding of environmental heterogeneity and ecological differences among species are key aspects to understand biodiversity patterns. Therefore, the study of spatial and environmental effects on biodiversity increased the recent years (Szava-Kovats and Parter, 2014). In the last few years, the research addressing relationship between environmental heterogeneity and biodiversity more focus on species identity than variety of functional diversity. Functional diversity is morpho-physiophenological that impact organism's fitness that also must be assessed to understand biodiversity pattern (Griselda et al. 2019). One of biodiversity pattern than needed to be assessed since it becomes lifeblood of the see is plankton. Their abundance and biodiversity determine food-webs for fish and major contributor for oxygen production.

The selection of sampling site for assessing plankton biodiversity in both rivers and lakes had been carried out with consideration of water flow (Astirin and Setyawan, 2000; Benarjee and Narasimha, 2013; Niken, 2019), activities in sampling site (Sentosa et al. 2017; Sofarini et al. 2019) and even using satellite imagery (Borro et al. 2005; Ausseil et al 2007; Mccullough et al. 2012; Torbick et al. 2013; Dong et al 2014; Rapinel et al 2015; Li et al. 2015; Thomas et al 2015; Pekel et al. 2016). However, 
there is ecosystem type different from above condition that also vital to be protected. The swamp ecosystem had its own uniqueness that was ecologically separated and different from the river during the dry season. Utilization of satellite imagery heretofore had only been limited in land cover and water body each year according to user needs so that the area of flood obtained was still annual. Changes in dynamic inundation required multi-temporal spatial data (Ahmed, 2012) as a database (Prasad et al. 2002) to map type of inundation globally (Tiner, 2004) that related to biophysical parameters (Herbert, 2012). Therefore, the aim of the study was to analyze the typology of inundation and plankton biodiversity in several inundations of the Paminggir Barito, South Borneo, Indonesia. The typology produced is as a solution in the utilization of inland fisheries activities in the Paminggir peatland with limited aquatic resources.

\section{MATERIALS AND METHODS}

\section{Study site}

This research has been carried out in Paminggir and Danau Panggang Districts, Hulu Sungai Utara Regency, South Kalimantan, Indonesia (Figure 1). Total of 10 sampling sites including Tampakang, Pandamaan, Ambahai, Palbatu, Bararawa, Sapala, Simpang Jenamas, Paminggir, and Sei Panangah Villages have been observed. The selection of location site is based on the ecoregion boundary of the Barito river and the Negara river $(43,275.38$ hectares) using delineation technique with coordinates $2^{\circ} 1$ '37' S until $2^{\circ} 35^{\prime} 58^{\prime \prime} \mathrm{S}$ and $114^{\circ} 50^{\prime} 58^{\prime \prime} \mathrm{E}$ until $115^{\circ} 50^{\prime} 24^{\prime \prime} \mathrm{E}$.

\section{Materials}

This research used Landsat imagery in June and July 1994, 2014 and 2019 (path row 125/61, 117/62 with < 10\% cloud cover) retrieved from http: //earthexplorer.usgs.gov/ and Indonesian Topographical maps of Hulu Sungai Utara. This research was only used Landsat imagery in June and July 1994, 2014 and 2015 since in these months was dry season and minimal inundation was observed clearly without influence of rainfall and main river runoff. The selection of the year is closely related to the El Nino phenomenon in Indonesia and the availability of image data. Mapping process was analyzed using following programs ENVI, GIS, Google Earth and Global Position System (GPS). Acoustic data were processed with supervised classification approach. Supervised classification approach are algorithm that learn pattern in data to predict an associated discrete class using programming computer. Supervised machine learning used was Maximum Likelihood Estimation because it has level of accuracy of more than $94,04 \%$, in heterogeneity area (Muhammad et al. 2016).

\section{Image processing and spatial analysis}

Landsat image processing begins with delineation of the study site based on ecological boundaries of Barito and Negara Rivers. Thresholding delineation technique was then used for classifying water bodies by dividing the image into pixel of water (dark) and non-water (light). Masking processes were performed in minimum and maximum values for water pixel segmentation. Thresholding can be done on singles or combinations of the band. Band 5 in Landsat TM are important channels to identify wetlands, especially swamps because of their ability to discriminate between water and non-water features (Manju et al. 2005). The combination of 543 and 654 channel is the best RGB band to detect the inundation. The Object-Separated image was used as a masking for classification.

Percentage of inundation was analyzed by using maximum likelihood classification. The maximum likelihood classification method is a classification technique that considers pixel opportunities to be classified into certain categories (Kelley et al 1998; Gwet 2002). This technique produces classes of water bodies and non-water bodies. The classification of water bodies includes rivers, reservoirs and open waters whereas non-water bodies includes vegetation, open space and settlement. The distribution of land cover change area are needed as a classification stage based on the desired category. The classification system for inundation typology uses Supervised Classification of 139 training areas assisted by ground-checking and groundtruthing. Ground-checking and ground-truthing were used Overall Accuracy (OA) and Cohen's Kappa Coefficient (Kelley et al. 1998; Gwet 2002; Viera and Garet 2005).

Waterbody changes both permanently or temporarily were calculated by overlay techniques from inundation in 1994, 2014 and 2019 combined with administrative boundary maps obtained from the Central Statistics Agency in 2018 and Indonesian topographic maps from the Geographic Information Agency. Calculation of the coverage of each inundation class from 1994, 2014 and 2019 was analyzed using GIS. This analysis results in the form of inundation area based on temporary and permanent classes so that it can be compared to the extent and the period of inundation either less than 1 period or more than 1 to 3 periods of inundation

\section{Plankton and water quality analysis}

Plankton sampling and field verification were carried out in June and July 2019. Sampling location of plankton was determined using typology of inundation as result of image analysis classification (Figure 1). Water quality parameters such as $\mathrm{pH}$, Dissolved Oxygen (DO) and temperature were also observed for supporting data. Water samples were taken using a five-liter of plankton chamber. The water was then filtered using plankton-net sized 25 mesh with the tip attached to a collection bottle. The collection bottle was removed and the water was transferred to a $20 \mathrm{ml}$ sample bottle. Subsequently, the water was preserved using $4 \%$ formalin. Identification of the plankton was carried out at the Hydro-ecobiology Laboratory of the Faculty of Fisheries and Marine Lambung Mangkurat University using a microscope and Sedgwick rafter. Plankton identification was based on guide book of Mizuno (1979) and Nedham and Nedham (1941). Diversity index was calculated based on the Shanon-Wiener index and evenness (Odum and Barrett 2004), using following formula: 
$\mathrm{H}=-\sum(\mathrm{ni} / \mathrm{N}) \ln (\mathrm{ni} / \mathrm{N})$

Where:

$\mathrm{H}$ : diversity index

ni: the number of individuals of each type

$\mathrm{N}$ : total number of individuals

The evenness was calculated with the following formula (Pielou 1966):

Pielou's evenness index ( $\mathrm{J}): \mathrm{J}=\mathrm{H}^{\prime} / \ln \mathrm{S}$

Where:

$\mathrm{S}:$ total species

H': diversity index

\section{RESULTS AND DISCUSSION}

Collection of water and plankton quality samples selected based on the results of typology analysis in both temporary and permanent areas. Plankton variations in permanent were more numerous compared to temporary areas. Biodiversity and water surface temperature variables showed almost the same conditions between locations, except the number of taxon, evenness. Although, the concentration of dissolved oxygen (DO) and $\mathrm{pH}$ were lowest in the permanent inundation.

\section{Paminggir peatland typology}

Landsat imagery as a primary data source between June to July 1994, 2014 and 2019 informed the pattern of surface water bodies that changed spatially-temporally during dry season. The swamp typology was divided into five classes on the basis of inundation duration consisting of non-inundation, low temporary, medium temporary, permanent 1 and permanent 2 (Figure 2). Areas with a category of permanent inundation 1 were water bodies that were still inundated but decreasing water debit was observed that characterized in pink color (Figure 2). Areas with a permanent inundated category 2 were water bodies that still exists although in dry season, characterized in blue color. The typology of permanent inundation decreased by $30 \%$ from 1994 to 2019 during dry season. Accuracy test on the results of typology analysis showed an overall accuracy value of $88.48 \%$ and 0.8 for the Kappa accuracy value. The results of typology classifications from 1994 to 2019 are summarized in Table 1.

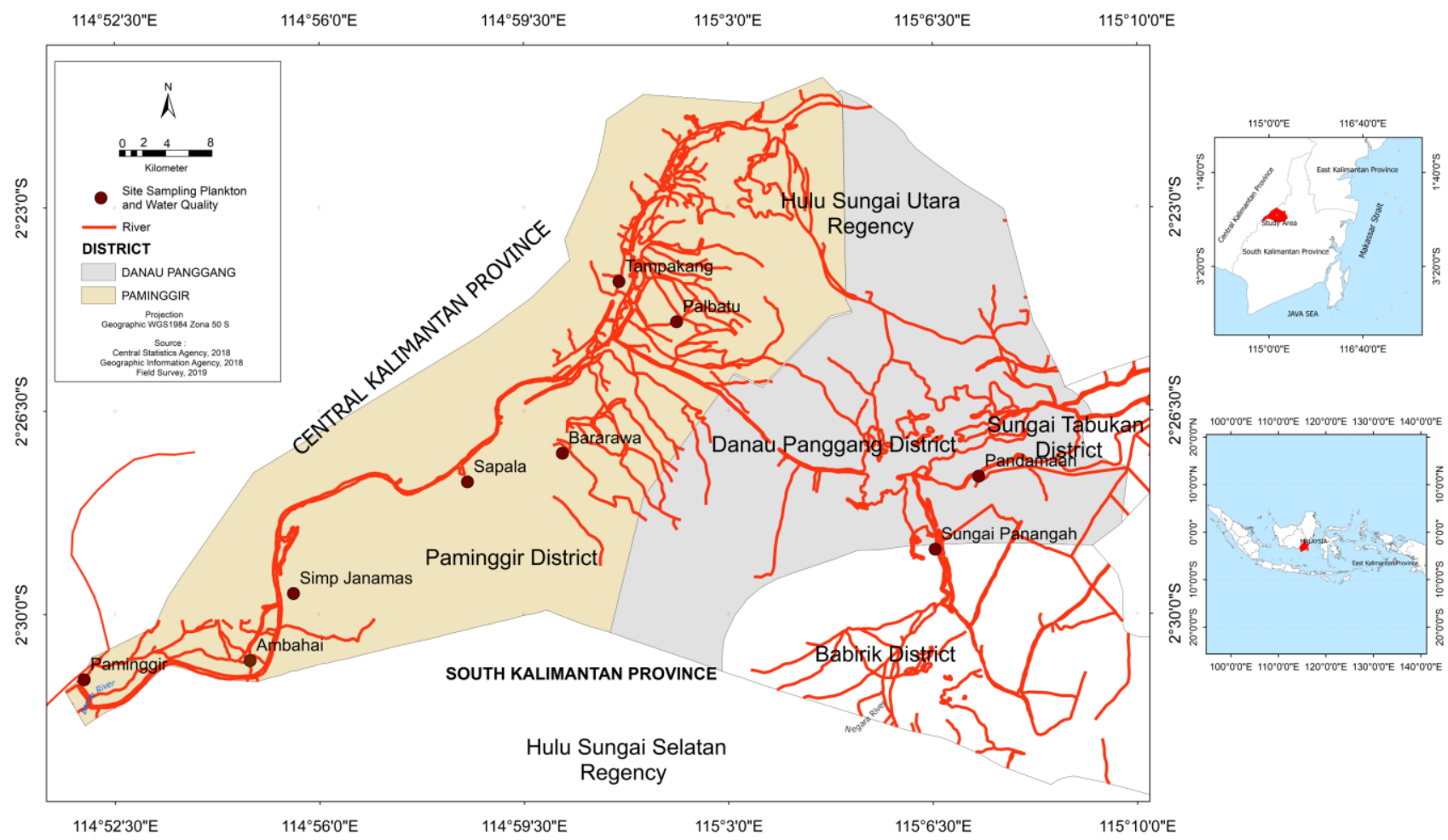

Figure 1. Sampling site of plankton and water quality on Paminggir peatlands, South Kalimantan, Indonesia

Table 1. Class of typology Paminggir peatland, South Kalimantan, Indonesia between June and July 1994, 2014 dan 2019

\begin{tabular}{lllllll}
\hline \multirow{2}{*}{$\begin{array}{c}\text { Class of typology } \\
\text { peatland }\end{array}$} & \multicolumn{2}{c}{$\mathbf{1 9 9 4}$} & \multicolumn{2}{c}{$\mathbf{2 0 1 4}$} & \multicolumn{2}{c}{$\mathbf{2 0 1 9}$} \\
\cline { 2 - 7 } & \multicolumn{1}{c}{ Area (ha) } & Area (\%) & Area (ha) & Area (\%) & Area (ha) & Area (\%) \\
\hline Non Inundation & $30,184.439$ & 69 & $30,542.619$ & 70 & $28,184.439$ & 65 \\
Temporary & $8,757.327$ & 20 & $10,102.703$ & 23 & $13,450.689$ & 29 \\
Permanent & $4,333.818$ & 10 & $2,630.584$ & 6 & $1,640.456$ & 4 \\
\hline
\end{tabular}


Table 2. Fito and zooplankton phylum in Paminggir Peatland, South Kalimantan, Indonesia between June and July 2019

\begin{tabular}{|c|c|c|c|c|c|}
\hline \multirow{3}{*}{ Site sampling } & \multirow{3}{*}{ Period } & \multicolumn{4}{|c|}{ Phylum } \\
\hline & & Cyanophyta & Chlorophyta & Chrysophyta & Zooplankton \\
\hline & & \multicolumn{4}{|c|}{ Genera } \\
\hline \multirow[t]{2}{*}{ Ambahai } & June & None & Gonatozygon, Chara sp., Roya & $\begin{array}{l}\text { Diatoma, Spirostomum, Pleurogsima, Rhopalodia } \\
\text { gibba, Coconeis, Corethron }\end{array}$ & $\begin{array}{l}\text { Euglypha tuberculata, Euglenopsis, } \\
\text { Phacus sp., Diaptomus }\end{array}$ \\
\hline & July & & Gonatozygon, Chara sp. & $\begin{array}{l}\text { Cymatopleura, Diatoma, Nitzschia, Synedra, } \\
\text { Coconeis, Corethron }\end{array}$ & Euglena deses, Phacus sp. \\
\hline \multirow[t]{2}{*}{ Tampakang } & June & & $\begin{array}{l}\text { Gonatozygon, Closterium, Hormidium, Roya, } \\
\text { Ankistrodesmus }\end{array}$ & $\begin{array}{l}\text { Cymatopleura, Diatoma, Navicula, Nitzschia, } \\
\text { Synedra, Coconeis, Corethron }\end{array}$ & Euglenopsis, Phacus sp., Nauplius \\
\hline & July & & Gonatozygon, Closterium, Hormidium, Roya & $\begin{array}{l}\text { Cymatopleura, Diatoma, Navicula, Nitzschia, } \\
\text { Melosira, Coconeis, Corethron }\end{array}$ & Phacus sp., Nauplius \\
\hline \multirow[t]{2}{*}{ Palbatu } & June & Coelastrum, Gloeocystis & Closterium, Tetmemorus, Ankistrodesmus & Diatoma, Navicula, Nitzschia, Coconeis, Corethron & $\begin{array}{l}\text { Euglypha tuberculata, Euglenopsis, } \\
\text { Notholca }\end{array}$ \\
\hline & July & Gloeocystis, Oscillatoria & Hormidium, Roya,Chara sp. & & Euglena deses, Phacus sp. \\
\hline Bararawa & $\begin{array}{l}\text { June } \\
\text { July }\end{array}$ & Oscillatoria & Gonatozygon, Chara sp. & $\begin{array}{l}\text { Cymatopleura, Diatoma, Nitzschia, Coconeis, } \\
\text { Corethron }\end{array}$ & $\begin{array}{l}\text { Euglena deses, Nauplius } \\
\text { Euglena deses, Phacus sp. }\end{array}$ \\
\hline Sapala & $\begin{array}{l}\text { June } \\
\text { July }\end{array}$ & Coelastrum & $\begin{array}{l}\text { Gonatozygon, Hormidium, Zygogonium } \\
\text { Gonatozygon, Hormidium }\end{array}$ & Diatoma, Synedra & Euglena deses, Euglenopsis \\
\hline \multirow[t]{2}{*}{ Simp Jenamas } & June & Gloeocystis & $\begin{array}{l}\text { Gonatozygon, Chara sp., Hormidium, } \\
\text { Ankistrodesmus }\end{array}$ & Cymatopleura, Corethron & Notholca \\
\hline & July & & Gonatozygon,Hormidium, Roya & Diatoma, Navicula, Nitzschia & Euglenopsis \\
\hline \multirow[t]{2}{*}{ Paminggir } & June & None & $\begin{array}{l}\text { Gonatozygon, Chara sp., Closterium, } \\
\text { Tetmemorus, Ankistrodesmus }\end{array}$ & Cymatopleura, Synedra & Euglypha tuberculata, Euglenopsis \\
\hline & July & & Gonatozygon, Hormidium, Roya, Closterium & Diatoma, Nitzschia & Euglenopsis \\
\hline \multirow[t]{2}{*}{ Pandamaan } & June & & Gonatozygon, Closterium, Hormidium, Roya & $\begin{array}{l}\text { Cymatopleura, Diatoma, Nitzschia, Navicula, } \\
\text { Coconeis, Corethron, Synedra }\end{array}$ & Nauplius, Phacus sp. \\
\hline & July & & Closterium, Hormidium, Roya, Chara sp., & $\begin{array}{l}\text { Cymatopleura, Diatoma, Nitzschia, Navicula, } \\
\text { Coconeis, Corethron, Melosira }\end{array}$ & Euglena deses, Phacus sp., Nauplius \\
\hline Sei Panangah & $\begin{array}{l}\text { June } \\
\text { July }\end{array}$ & & $\begin{array}{l}\text { Gonatozygon, Closterium, Ankistrodesmus } \\
\text { Gonatozygon, Hormidium, Closterium }\end{array}$ & Diatoma, Coconeis & $\begin{array}{l}\text { Euglenopsis, Phacus sp. } \\
\text { Euglena deses, Phacus sp. }\end{array}$ \\
\hline
\end{tabular}




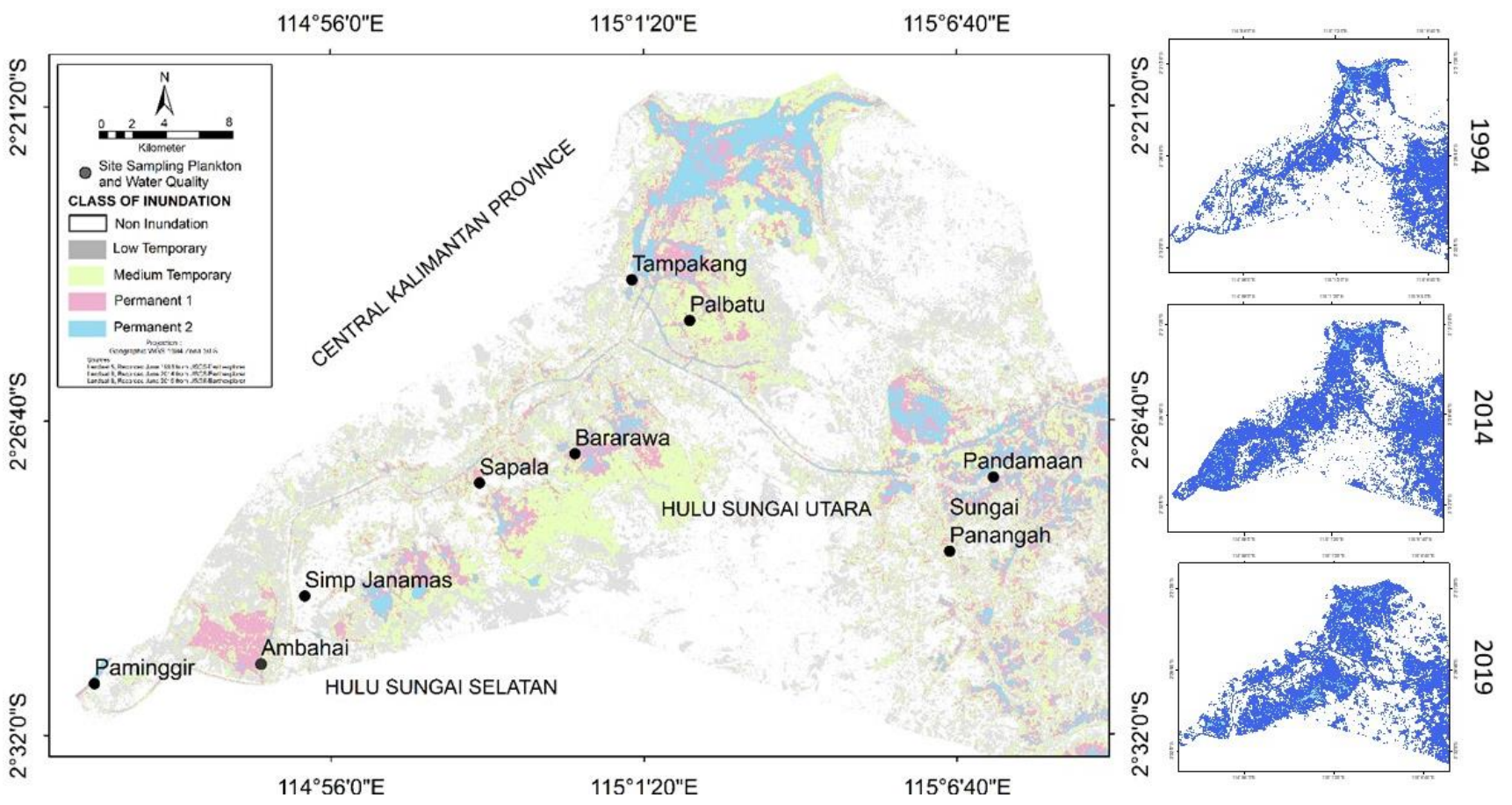

Figure 2. Typology of Paminggir peatland, South Kalimantan, Indonesia inundation between June and July 1994, 2014 and 2019

\section{Plankton community structure}

The distribution of the Chrysophyta more dominates than Chlorophyta and Cyanophyta I (Table 2). The Cyanophyta phylum only presented in 4 locations, while Chlorophyta was spread in all observation stations but the population was not as much as Chrysophyta. Zooplankton was more diverse in the Tampakang, Ambahai and Palbatu areas (Table 2). The composition of plankton in freshwater mainly had less than marine ecosystems (Dodson et al. 2009; Rahayu et al. 2013; Widyarini et al. 2017) shown in Figure 3.

\section{Inundation typology, plankton biodiversity, and water quality}

Plankton biodiversity component which was indicated as index of diversity, evenness, and taxon informed that the duration of inundation period had an impact on the dynamics of plankton (Figure 3). Diversity and the quantity of taxon identified were increased in typology of permanent but decreased in temporary.

In line with plankton biodiversity indicators (diversity, evenness and quantity of taxa) in response to environmental typology conditions in peatland waters, surface temperature components were not affected by inundation typology patterns, while other water quality such as $\mathrm{pH}$ and dissolved oxygen as a limiting factor (Schagerl et al. 2009; Chaparro et al. 2018; Sofarini et al. 2019; Siriwardana et al. 2019) gave a significant response to inundation typology (Figure 4). Temperature values between $28.1{ }^{\circ} \mathrm{C}$ to $30.6{ }^{\circ} \mathrm{C}$ did not have an impact on the type of inundation both permanent and temporary. Dissolved oxygen $5.7 \mathrm{mg} / \mathrm{l}-6,1 \mathrm{mg} / \mathrm{l}$ indicated that the temporary typology was higher in dissolved oxygen supply than in permanently flooded areas. $\mathrm{pH}$ below 5 were areas with permanent inundation, whereas above values 5 were temporary inundated areas, except for Pandamaan and Simpang Jenamas that differed from their typology.

The parameter values of dissolved oxygen and extreme $\mathrm{pH}$ were in line with the duration of inundation so that plankton in their development were more diverse due to the lack of circulation by water currents. The mechanism of water circulation caused normal water quality and stable plankton dynamics that were in harmony with each typology of peatland.

\section{Discussion}

Limitation of water supply from the Barito river runoff and Nagara in the Paminggir peatland in the dry season formed separate inundation areas that had different typologies. Each inundation provided plankton as a natural source of food for fish. The composition and existence of phytoplankton and zooplankton both from diversity and species distribution in swamp were directly related to the characteristics of inundation both permanent and temporary. Peatland typology, plankton availability and water quality were the compositions that build the fundamental structure of inland fisheries development (Salam et al. 2005; Sakamoto et al. 2009; Herbert et al. 2012; Nguyen et al. 2016). 


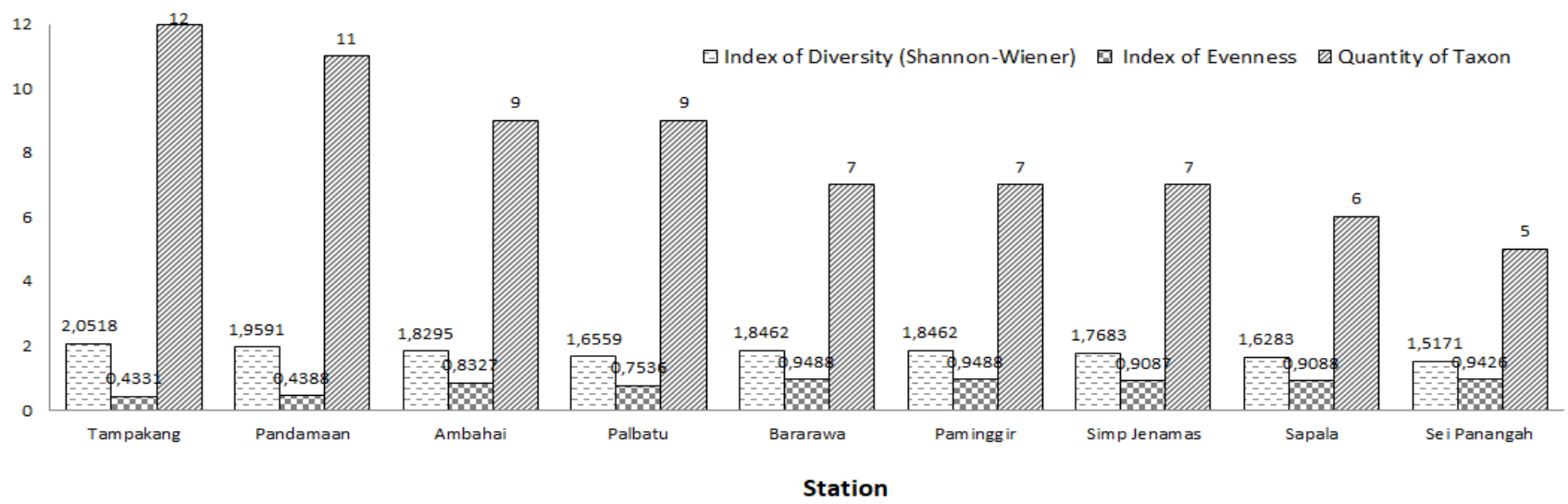

Figure 3. Index of diversity, evenness and quantity of taxon at temporary and permanent inundation Paminggir Peatland, South Kalimantan, Indonesia

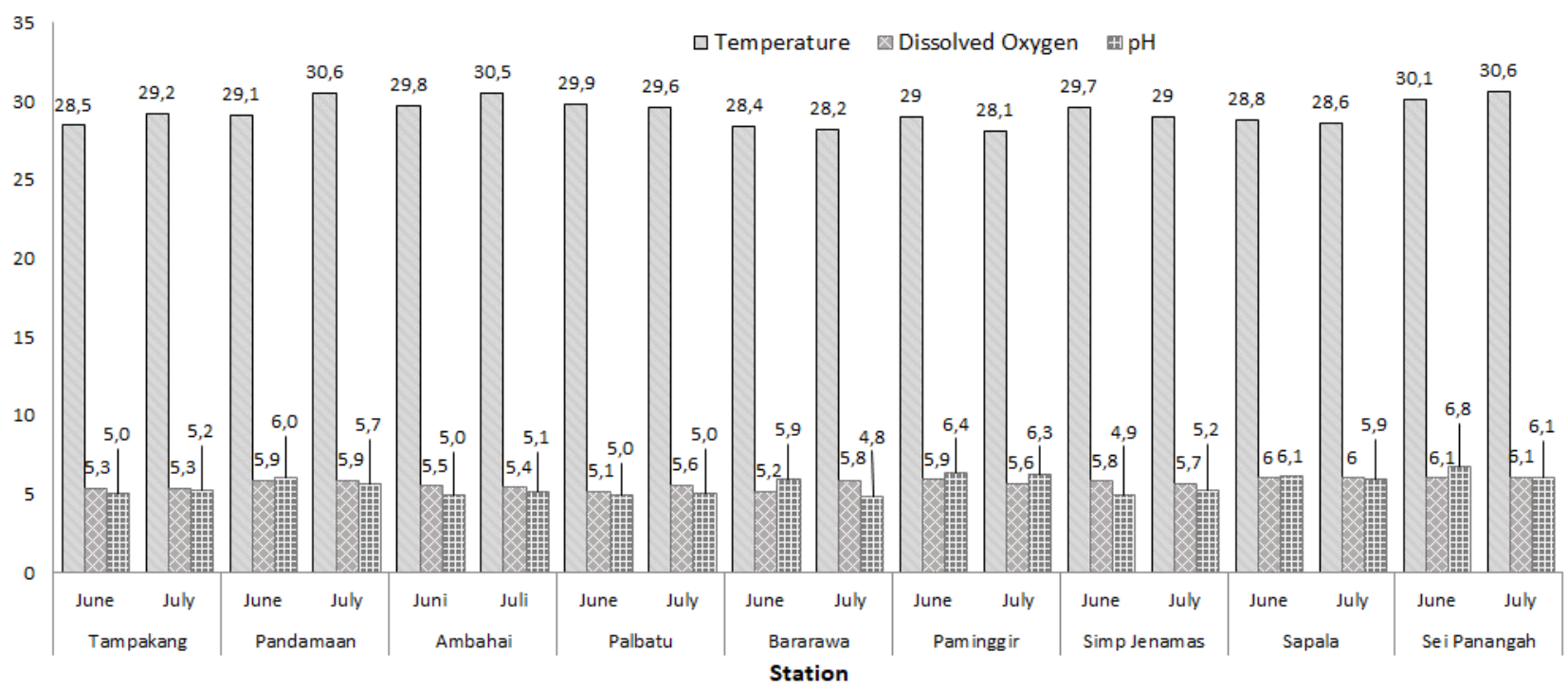

Figure 4. Temperature, Dissolved Oxygen, and $\mathrm{pH}$ values in the peatland water of Paminggir, South Kalimantan, Indonesia between June and July 2019

The temporary inundation in Paminggir peatland tends to increase compared to permanent inundation for recent 25 years. The inundated areas consist of shrubs and former logging close to the Barito and Nagara River whereas permanent inundation was as water reservoir (Chen and Wong, 2016; Grand-Clement et al. 2015) in peatland ecosystem on dry season. The Tampakang and Pandamaan regions were categorized into permanent class 2 with wider basins for water reservoirs compared to other regions. Moreover, this area functioned as peat conservation and still preserved a natural forest ecosystem bordering Central Kalimantan (Desa Pasar Panas and Jenamas). Ambahai, Palbatu, and Bararawa Belakang were classified as permanent class 1 which still had a flood of water during the dry season but in a reduced quantity. Sapala, Paminggir, Simpang Jenamas, and Panangah River, although included in the class of inundated temporarily, water source through the runoff of the Barito River and Negara was always available. Runoff variability during the dry season was relatively low compared to when it rained which causes potential drought in each five-year cycle.

The composition of the Chrysophyta dominated in terms of presence and quantity compared to Chlorophyta and Cyanophyta which were commonly found in freshwater. Chlorophyta and Cyanophyta were the phytoplankton types that quickly replicated when there was an increase in organic matter so that the quality of the aquatic environment was unstable (Zalocar et al. 2007; Chellappa et al. 2008; Imai et al. 2009). Cyanophyta species such as Oscillatoria sp., and Anabaena sp., Actinomyces (Jüttner and Watson 2007; Giglio et al. 2010) as a cause of fish smelling of mud (Padmavathi and Veeraiah 2009). Chlorophyta could dominate the waters known as eutrophication, while Chrysophyta is 
phytoplankton better known as diatom (Mujiyanto et al. 2011) which was also consumed by Climbing perch fish and Catfish (Roy et al. 2011). Furthermore, there were also Navicula $s p$., which were preferred by omnivorous fish (Bucholtz et al. 2009). The existence of zooplankton contributed to the existence of potential fish resources (Thirunavukkarasu et al 2013) because it played a dual role as a first-level and second-level consumer connecting plankton and nekton (Pratono et al. 2012). The majority of Zooplankton found in this study were from the phyla Crustacea, Euglenophyta, Aschelminthes and Protozoa. Protozoa were more numerous than others because of their ability to survive in adverse environmental by forming cysta and had shorter reproduction stages than other classes (Widyarini et al. 2017). The role of nauplius in waters were as food for fish larvae and juveniles (Llyova and Kubicek 2002; Sales 2011; Alfonso and Belmonte 2011).

The diversity index was categorized as medium with $1<\mathrm{H}^{\prime}$ (Shannon-Wiener) $<3$ that showed moderate distribution, sufficient productivity, balanced ecosystem conditions, and moderate ecological pressure. The diversity index of plankton did not differ between temporary and permanent inundation, although in the Tampakang area has 2.0518 , but it was still categorized as medium (Manson, 1981; Sugianti et al. 2015). The largest number of plankton taxon was found in Tampakang, followed by Pandamaan, Ambahai, Palbatu which were categorized as permanent inundation, while Paminggir, Simp Jenamas, Sapala, and Sei Panangah which were categorized as temporary inundation had number of taxon of 7, 6 and 5 .

Index of evenness was inverse to index of diversity so that the higher evenness was a temporary area. This opinion was supported by Wijenayake et al. (2014); Chandrasoma and Pushpalatha (2018) that revealed the high index of diversity indicated that at this location it was feasible in terms of the availability of natural food for inland fisheries activities. On the other hand, temperature, sunlight, dissolved oxygen and $\mathrm{pH}$ were important components of plankton life and growth in various inundation. The $\mathrm{pH}$ value of less than 5 would not be able to be resisted by other freshwater fish like Cyprinidae but not for Anabantidae that can survive in the peatland with low $\mathrm{pH}$.

In conclusion, Supervised classification-based methods proofed by ground-checking was a valuable technique to determine the typology of inundation in swamp area. The accuracy value of the peatland typology of overall accuracy and Kappa was $88.48 \%$ and 0.8 where the Kappa value between 0.61 and 0.8 represented a substantial category. The typology of permanent inundation in the Tampakang, Pandamaan, Ambahai, Palbatu, and Bararawa areas have more plankton diversity than temporary areas. Moreover, the concentration of dissolved oxygen (DO) and $\mathrm{pH}$ were of extreme value in permanent inundation. This study provided a baseline of inland fisheries activities based on natural feed in the Hulu Sungai Utara throughout the season.

\section{REFERENCES}

Ahmed F. 2012. Detection of change in vegetation cover using multispectral and multi-temporal information for District Sargodha, Pakistan Soc Nat 24: 557-572.

Alfonso G, Belmonte G. 2011. Calanoida (Crustacea: Copepoda) from the inland waters of Apulia (south-eastern Italy). J Limnol 70: 57-68

Astirin PO, Setyawan AD. 2000. Plankton biodiversity at Jabung Swamp, Lamongan and Tuban Districts. Biodiversitas 2: 65-71

Ausseil AGE, Dymond JR, Shepherd JD. 2007. Rapid mapping and prioritisation of wetland sites in the Manawatu-Wanganui region, New Zealand Environ Manag 39: 316-325

Benarjee G, Narasimha RK. 2013. Physico-chemical factors influenced plankton biodiversity and fish abundance-A case study of Nagaram Tank of Warangal, Andhra Pradesh. Intl J Life Sci Pharm Res 2: 248260

Borro M, Morandeira N, Salvia M, Minotti P, Perna P, Kandus P. 2005. Mapping shallow lakes in a large South American floodplain: A frequency approach on multitemporal Landsat TM/ETM data. J Hydrol 75: 5-23.

Bucholtz RH, Meilvang AS, Cedhagen T, Christensen JT. 2009. Biological Observations on the Mudskipper Pseudapocryptes elongatus in the Mekong Delta, Vietnam. J World Aquac Soc 40: 711-723

Chandrasoma J, Pushpalatha CKB. 2018. Fisheries enhancements in inland waters in Sri Lanka with special reference to culture-based fisheries: current status and impacts. J Aquat Sci 23: 49-65

Chaparro G, Horvath Z, Ines O'Farrell, Ptacnik R, Thomas H. 2018. Plankton metacommunities in floodplain wetlands under contrasting hydrological conditions. Freshw Biol 63 (3): 1-12.

Chellappa NT, Borba JM, Rocha O. 2008. Phytoplankton community and physical-chemical characteristics of water in the public reservoir of Cruzeta, RN, Brazil. Braz J Biol 68: 477-494

Chen ZR, Wong MH. 2016. Integrated wetlands for food production. Environ Res 148: 429-442

Cooke SJ, Allison EH, Beard TD, Arlinghaus R, Arthington AH, Bartley DM, Cowx IG, Fuentevilla C, Leonard NJ, Lorenzen K, Lynch AJ, Nguyen VM, Youn S-J, Taylor WW, Welcomme RL. 2016. On the sustainability of inland fisheries: Finding a future for the forgotten. Ambio 45: 753-764.

Dodson SI, Newman AL, Will-Wolf S, Alexander ML, Woodford NP. 2009. The relationship between zooplankton community structure and lake characteristics in temperature lakes (Northern Wisconsin, USA). J Plankton Res 31: 93-100.

Dong Z, Wang Z, Liu D, Song K, Li L, Jia M, Ding Z. 2014. Mapping wetland areas using Landsat-derived NDVI and LSWI: A case study of West Songnen plain, Northeast China. J Indian Soc Remote Sens 42: $1-8$.

FAO [Food and Agriculture Organization]. 2011. Guidelines for the ecolabelling of fish and fishery products from inland capture fisheries. Food and Agriculture Organization, Rome, Italy.

Giglio S, Chou WKW, Ikeda H, Cane DE, Monis PT. 2010. Biosynthesis of 2-methylisoborneol in cyanobacteria. Environ Sci Technol 45: 992998

Grand-Clement E, Anderson K, Smith D, Angus M, Luscombe DJ, Bray LS, Brazier RE, Gatis N. 2015. New approaches to the restoration of shallow marginal peatlands (Review). J Environ Manag 161: 417-430.

Griselda C, Inés O, Thomas H. 2019. Multi-scale analysis of functional plankton diversity in floodplain wetlands: Effects of river regulation. Sci Total Environ 667: 338-347.

Gwet K. 2002. Kappa statistic is not satisfactory for assessing the extent of agreement between raters. Stat Methods Inter-Rater Reliab Assess 76: $378-382$.

Herbert S, Tollner EW, Karen V. 2012. Geospatial modelling of site suitability for pond-based Tilapia and Clarias farming in Uganda. J Appl Aquac 24: 147-169.

Imai H, Chang KH, Kusaba M, Nakano SI. 2009. Temperature-dependent dominance of Microcystis (Cyanophyceae) species: Microcystis aeruginosa and Microcystis wesenbergii. J Plankton Res 31: 171-178

Jüttner F, Watson SB. 2007. Biochemical and ecological control of geosmin and 2-methylisoborneol in source waters. Appl Environ Microbiol 73: 4395-4406.

Kelley GW, Hobgood JS, Bedford KW, Schwab DJ. 1998. Generation of three-dimensional lake model forecasts for Lake Erie. Weather Forecast 13: 305-315. 
Li L, Chen Y, Xu T, Liu R, Shi K, Huang C. 2015. Super-resolution mapping of wetland inundation from remote sensing imagery based on integration of back-propagation neural network and genetic algorithm. Remote Sens Environ 164: 142-154.

llyova M, Kubicek F. 2002. Crustaceans (Crustacea: Cladocera, Copepoda) of the Morava River alluvium on the Slovak territory. Acta Soc Zool Bohemic 66: 205-212

Lynch AJ, Cowx IG, Fluet-Chouinard E, Glaser SM, Phang SC, Bower SD, Brooks JL, Bunnell DB, Claussen JE, Cooke SJ, Beard TD, Kao YC, Myers BJE, Reid AJ, Taylor JJ, Youn S, Lorenzen K. 2017 Inland fisheries-Invisible but integral to the UN Sustainable Development Agenda for ending poverty by 2030. Glob Environ Change 47: 167-173

Manju G, VM Chowdary YK, Srivastava S, Selvamani A, Jeyaram S, Adiga. 2005. Mapping and characterization of inland wetlands using remote sensing and GIS. J Indian Soc Remote Sens 33: 51-66.

Manson CF. 1981. Biology of Freshwater Pollution. Longman, London

Mccullough IM, Loftin CS, Sader SA. 2012. Combining lake and watershed characteristics with Landsat TM data for remote estimation of regional lake clarity. Remote Sens Environ 123: 109-115.

Mizuno T. 1979. Illustrations of The Freshwater Plankton of Japan. Hoikusha Publishing, Japan.

Muhammad AM, Rombang JA, Saroinsong FB. 2016. Identification of land close type in poigar KPHP area with maximum likelihood method. Cocos 7: 1-9. [Indonesian]

Mujiyanto DW, Tjahjo H, Sugianti Y. 2011. The relationship between phytoplankton abundance and $\mathrm{N}$ : $\mathrm{P}$ concentration ration at cage aquaculture area in Ir. H. Djuanda reservoir. Jurnal Limnotek 18: 1525.

Needham JG, Needham PR. 1941. A Guide to the Study of Fresh-Water Biology. Comstock Publishing Company Inc., New York.

Nguyen VM, Lynch AJ, Nathan Y, Cowx IG, Beard DT, Taylor WW, Cooke SJ. 2016. To manage inland fisheries is to manage at the social-ecological watershed scale. J Environ Manag 181:312-325.

Niken TM, Pratiwi. 2019. Community structure of plankton at Central Kalimantan Peat Swamp Area. IOP Conf Series: Earth Environ Sci 298: 012003. DOI: 10.1088/1755-1315/298/1/012003.

Odum E, Barrett GW. 2004. Fundamentals of Ecology. 5th ed. Cengage, Boston, MA.

Padmavathi P, Veeraiah K. 2009. Studies on the influence of Microcystis aeruginosa on the ecology and fish production of carp culture ponds. Afr J Biotechnol 8: 1911-1918.

Pekel JF, Cottam A, Gorelick N, Belward AS. 2016. High-resolution mapping of global surface water and its long-term changes. Nature 540-548.

Pielou EC. 1966. Species-diversity and pattern-diversity in the study of ecological succession. J Theo Biol 10: 370-383

Prasad SN, Ramachandra TV, Ahalya N, Sengupta T, Kumar A, Tiwari AK, Vijayan VS, L Vijayan. 2002. Conservation of wetlands of Indiaa review. Trop Ecol 43: 173-186.

Pratono BA., Ambariyanto M, Zainuri. 2012. Struktur komunitas zooplankton di muara Sungai Serang. Jakarta. Indonesian J Mar Sci 10: 90-97.

Rahayu S, Setyawati TR, Turnip M. 2013. Struktur komunitas zooplankton di Muara Sungai Mempawah Kabupaten Pontianak berdasarkan pasang surut air laut. Jurnal Protobiont 2: 49-55. [Indonesian]

Rapinel S, Bouzillé JB, Oszwald J, Bonis A. 2015. Use of bi-seasonal Landsat-8 imagery for mapping marshland plant community combinations at the regional scale. Wetlands 35: 1-12.

Roy D, Masud AA, Bhouiyan NA, Naser MN. 2013. Food and feeding habits of climbing perch Anabas testudineus (Bloch) and indigenous catfish Rita rita (Hamilton). Intl J BioRes 15: 1-6.
Sakamoto T, Phung CV, Kotera A, Nguyen KD, Yokozawa M. 2009. Analysis of rapid expansion of inland aquaculture and triple ricecropping areas in a coastal area of the Vietnamese Mekong Delta using MODIS time-series imagery. Landsc Urban Plan 921: 34-46.

Salam MA, Khatun NA, Ali MM. 2005. Carp farming potential in Barhatta Upazilla, Bangladesh. Aquaculture 245: 75-87.

Sales, J. 2011. First feeding of freshwater fish larvae with live feed versus compound diets: a meta-analysis. Aquacult Int 19: 1217-1228.

Schagerl M, Drozdowski I, Angeler DG, Hein T, Preiner S. 2009. Water age-a major factor controlling phytoplankton community structure in a reconnected dynamic floodplain (Danube, Regelsbrunn, Austria). J Limnol 68: 274-287.

Sentosa DA, Hedianto H, Satria. 2017. Eutrophication potential in lake matano based on its phytoplankton community and water quality. Limnotek 24: 61-73.

Siriwardana C, Asitha T, Cooray, Sudantha S, Liyanage SM, Koliyabandara PA. 2019. Seasonal and spatial variation of dissolved oxygen and nutrients in Padaviya Reservoir, Sri Lanka. J Chem 2019: 5405016. DOI: $10.1155 / 2019 / 5405016$

Sofarini D, Herawati EY, Mahmudi M, Hertika AMS, Arfiati D, Musa M, Amin M, Supriharyono. 2019. Analysis of stomach content of piscivorous fishes caught in Danau Panggang Peatland, South Kalimantan, Indonesia. Biodiversitas 20: 3788-3793.

Sugianti Y, Putri MRA, Krismono. 2015. Community characteristic and phytoplankton abundance in Talaga lake, Central Sulawesi. Limnotek 22: 86-95.

Szava-Kovats RC, Meelis Partel. 2014. Biodiversity patterns along ecological gradients: unifying b-diversity indices. PLoS One 9 (10): e110485. DOI: 10.1371/journal.pone.0110485

Thirunavukkarasu K, Soundarapandian P, Varadharajan D, Gunalan B. 2013. Zooplankton Composition and Community Structure of Kottakudi and Nari Backwaters, South East of Tamil Nadu. J Environ Anal Toxicol 4: 200.

Thomas RF, Kingsford RT, Lu Y, Cox SJ, Sims NC, Hunter SJ. 2015. Mapping inundation in the heterogeneous floodplain wetlands of the Macquarie Marshes, using Landsat Thematic Mapper. J Hydrol 524: 194-213.

Tiner R. 2004. Remotely-sensed indicators for monitoring the general condition of "natural habitat" in watersheds: An application for Delaware's Nanticoke River watershed. Ecol Indic 4: 227-243.

Torbick N, Hession S, Hagen S, Wiangwang N, Becker B, Qi J. 2013. Mapping inland lake water quality across the lower Peninsula of Michigan using Landsat TM imagery. Int J Remote Sens 34: 76077624

Trinugroho MW, Mawardi. 2017. The Use of Remote sensing for Monitoring of Inundation Area on fresh Swampland. Jurnal Ilmiah Geomatika 23: 49-56.

Viera AJ, Garrett JM. 2005. Understanding inter-observer agreement: the kappa statistic. Fam Med 37: 360-363.

Widyarini H, Niken TM, Pratiwi, Sulistiono. 2017. Zooplankton community structure at Majakerta estuary and its surrounding waters, Indramayu Regency, West Java Province. Jurnal Ilmu dan Teknologi Kelautan Tropis 9: 91-103.

Wijenayake WMHK, Gunaratne ABAK, De Silva SS, Amarasinghe US. 2014. Use of geographical information system and remote sensing techniques for planning culture-based fisheries in non-perennial reservoirs of Sri Lanka. Res Manag 19: 183-191.

Zalocar de Domitrovic Y, Poi de Neiff ASG, Casco SL. 2007. Abundance and diversity of phytoplankton in the Paraná River (Argentina) 220 $\mathrm{km}$ downstream of the Yacyretá reservoir. Braz J Biol 67: 53-63. 